\title{
The Reception of the Indo-European Concepts of King and Hero (Based on M.L. West) in Contemporary Art*
}

\author{
Liudmila Volkova \\ People's Friendship University of Russia (RUDN \\ University) \\ 6 Miklukho-Maklaya St. \\ Moscow, Russian Federation 117198 \\ E-mail: volkova.1.1@mail.ru
}

\author{
Vladimir Zhdanov \\ People's Friendship University of Russia (RUDN \\ University) \\ 6 Miklukho-Maklaya St. \\ Moscow, Russian Federation 117198 \\ E-mail: vvpaulistano@mail.ru
}

\begin{abstract}
Poetry, legends, myths are transmitters of traditions and language in the Indo-European world. They had determined the common values, images and categories that later formed the culture of these peoples. By examining the heritage of the Indo-Europeans we can identify the common structures in languages, the archetypes, the values of culture, which formed the mind and the evolution of these nations. Based on the analysis of the concepts "king" and "hero", this article examines the interpretation of these matters in the modern art.
\end{abstract}

Keywords-pre-philosophy; myth; mythology; concepts; contemporary art

\section{INTRODUCTION}

The developed mythological worldview composed the pre-philosophy - a special form of spiritual culture of ancient people which chronologically preceded the establishment of a complete philosophical worldview and which was structured in three main elements: the myth, the didactic tradition (conventional wisdom) and the foundations of scientific knowledge. M. L. West undertakes the study of Indo-European poetry and myths to establish not only the etymological and semantic similarity of words and concepts of these languages, but also the deep similarity of their conceptual content. In myths, we encounter a large number of concepts - words that possess a whole range of meanings that are related to each other and appear depending on the context. The concepts of hero and king were ones of the most inspiring as they provided the human with the model of the behavior and with the feelings of confidence, courage and motivation.

\section{THE KING CONCEPT}

"A king may himself be a hero, but in most cases the

*This paper was financially supported by the Ministry of Education and Science of the Russian Federation on the program to improve the competitiveness of Peoples' Friendship University (RUDN University) among the world's leading research and education centers in the 2016-2020 (The Agreement number 02.A03.21.0008) roles are distinct. The outstanding hero - one may think of Achilles, Hector, Jason, Heracles, Arjuna, Beowulf, $\mathrm{Cu}$ Chulainn, Lancelot - is usually not identical with the king. The king is remembered for kingly virtues such as justice, prosperity, liberality, or his lack of them; the hero for achievement, for overcoming adversity (whether on the king's behalf or inflicted by him)." [1] The king has many functions. For example, he rights the world, making the reality correct through his just and wise rule. The king must be a sort of the perfect father that controls his subjects as children, which is why he must be wise and fair, he must protect his people from various threats (both external and internal enemies, for example, of discord and enmity).

In our opinion, in the image of the king embodies the ideals of man, his "super-I", which is superimposed on the figure of the father, which is why the ruler plays a dual role: on one hand he is a merciful father, close and fair, and on the other hand, the presence of all other qualities brings him closer to the gods, the king cannot be compared with an ordinary man, as his figure in its properties approaches the image of the Supreme God, who controls the rest of the Pantheon. Furthermore, there is a conception of the divine origin of rule. For example, we can proceed to the conception mentioned in Scandinavian myths. "The Song about Riga tells that during one of the visits to people Esir Rig took the child, gave him knowledge of runes, called him Jarl-Rigr and made him his son. After God adopted him, Jarl went to conquer the lands. ... At the end of the Song about Riga Jarl calls his younger son Kon Ung (KonrUngr), which translates as "young offspring", and in folk etymology corresponds to the word "konung" (konungr) - old Norse term for the Supreme ruler, which in the Middle ages is identical to the concept of "king"." [2] This interpretation of the image of the king in the Indo-European tradition is different from the one that existed in the cultures of the Ancient Middle East, especially Ancient Egypt: there the king traditionally acts not just as a vicar of God or a mediator between the gods and the world of people, but he was originally a God. This feature is clearly manifested in the material of ancient Egyptian mythology. In particular, in a 
number of hymns and ritual inscriptions of the beginning of the New Kingdom (XV century BC) Amun, originally a local deity of Thebes, and later the Supreme God of the Egyptian Pantheon, is referred to not only as "king of the gods", but also as "God-king". Another striking example of the absolute divinity of the king in the Egyptian culture of the New Kingdom, we see in the era of Amarna, when Amenhotep IV (Akhenaton) systematically endowed not only the attributes of the son of the solar deity Aton, but also repeatedly referred to in the official texts of "the Unique for the Sun", that is a full deity. Thus, both traditional Egyptian polytheism and Amarna theology were characterized by the interpretation of the king's image not just as the son of God, but as God. It is in this last "incarnation" that the king acts not only as a mediator between the world of people and other gods, but also as the main guardian of Maat, the sacred order established in the world at the time of his creation. "With the land united under a stable monarchy, and with the institution of the kingship deified by its association with the figures of Horus and Osiris, the former of these deities being actually incarnate in the ruling monarch, there was need of no other signs or symbols of both natural and political stability. The very person of the monarch served as a guarantee that the reality of Maat could not be permanently threatened in the political and social order; the ruler himself was expected to function as the effective agent of maintaining Maat and restoring it whenever it might be thrown out of balance through some accident or mistake in human action." [3] This feature of the image of the king is the most important for the ancient Egyptian ethics, both religious and political. It is important to note that the preservation of this order by the king was represented in Egyptian religion and mythology as a continuous process, as Maat is under constant threat from the forces of chaos and darkness. Their main embodiment is the gigantic serpent Apophis, arch-enemy of the Sun-God. As a God, the king alone gives gifts and sacrifices to other gods, including the Sun-God. The original divinity of the king in Egyptian culture since the era of the Old Kingdom was expressed not only in ritual, but also in language. And Sun-God, and king traditionally were called "gods": the first as the "great God", the second as the "young God". Consequently, the image of the king as an" ideal man", mentioned above as characteristic of the Indo-European cultural tradition, is not always applicable to the cultures of the Ancient Middle East, in particular, Ancient Egypt. In our opinion, this is primarily due to the exceptional centrality of the ancient Egyptian state system, which led to the strengthening of the divine element in the interpretation of the nature of the king. Despite the fact that the problem of the divinity of the king in ancient cultures has been actively considered in world historiography for more than a century, many aspects of it require, in our opinion, further clarification in relation to the material of various ancient cultures.

\section{THE HERO CONCEPT}

The hero initially stands out of all the people because of his nature: hardiness, high growth, great strength, intelligence. Usually his superpowers are explained by the fact that he comes from the gods (god is at least one of his true parents), but as a result of certain circumstances the child turned out among ordinary people. However, he soon shows his outstanding abilities and becomes a warrior. The death of the hero is a separate topic in the story. Usually he is credited with almost complete invulnerability, and so he dies rather by treachery or treason than by the fair fight. The perpetrators of his death are usually punished by fate, and the hero goes to heaven (or to a feast of gods) in a blaze of glory and remains in the memory of his people.

The place of the woman in the narrations about the heroes is almost always secondary. Either she forces the hero to show his strength (to win her as a wife or to return her if she was taken from him by enemy), or she plays the role of some scenery, creates conditions for his life or death. "Many readers will think of Hector and his anxious, loving wife. But the Homeric epic has evolved to an exceptional level of sophistication and tasteful artistry; the characters are fleshed out with all kinds of realistic human detail to a degree unparalleled in other ancient traditions, and a figure such as Hector the family man is the product of this process." [4] Children of the hero also play minor roles. Either they are a sacrifice (the child is killed by the hero's enemy in order to make him act or the hero himself sacrifices the child to the gods), or the son only helps his father, but cannot overshadow his glory.

In the image of the hero, in our opinion, embody the dreams of the deed of each person. The hero becomes a model of behavior, especially for soldiers, the songs about the victories of this hero raise up for a battle, which is why the bards and storytellers use myths and legends about the heroes as the most illustrative example: the hero is, in fact, the same person who lived a little earlier, had the power, but who managed to direct this force to the feats. The behavior model of the hero sets the right example for all other men, as well as the behavior model of the mythical kings of the past defines the ideal behavior of the current kings. This feature is fundamental to the entire mythological worldview: the traditional myth always represents the past as a sacred time, a model for the present and the future.

With the help of the heroic deeds the man overcome not only the hardships of life, but tried to go beyond his own mortality. Glory that surrounded the hero gave him the opportunity to acquire immortality at least in songs and tales, in the memory of people. Moreover, the repetition of the heroes' actions opened the world to a man and a man to the world. "...ancient mythology should be considered as a chronicle of the eternal struggle of the old and the new, as a story about human life, its joys and sorrows, about its creativity and work, about the eternal human desire for a better future". [5]

It is important to note that both the hero and the king possess a number of qualities that are inherent in both of them. These qualities are courage, strength, nobility and honor. However, the king is also more inherent in wisdom, justice, and some cunning, which allows him to rule over people and create the promised land. At the same time, the hero has the qualities of a berserker, he is often brave to recklessness, he is principled, and with his appearance he 
motivates his allies and puts enemies to flight. But all these qualities also suggest that the king as a figure is selfsufficient, he is enclosed in himself and shows these qualities from his own essence, while the hero expresses himself through social interaction, through contrast with other people. In other words, the king creates his own rule, and the circumstances create a hero.

\section{THE CONCEPTS IN THE CONTEMPORARY ART}

Contemporary culture builds its attitude to myth in two ways. On the one hand, art is formed within the language, in which concepts play a huge role in the formation of human outlook, and therefore, works of art demonstrate myths and their images in modern vision, but with the preservation of traditional connotations. On the other hand, modern culture is characterized by the desire to de-mythologize, deconstruct the myth and create new images. The splitting of the images used in the myth for their understanding and formation of a new cultural reality is typical for the culture of postmodern. At the same time, the characters of some concepts remain the same. Thus, the hero becomes a model for action, motivates not to give up, go own way, follow the destination. He embodies the super-ego of the modern man, indicates the ideal of his aspirations, as well as the path to its realization. The king as a kind of archetype of the merciful father becomes the mentor of the hero, the one who guides and gives advice, forms the essence of the new hero. Anyway all these aspects manifest themselves in almost every narrative, especially in mass culture: in movies, books, etc. the figures of king and hero had undergone the least changes in such genres as science fiction, fantasy, history. Man forms a new myth, using old concepts to meet the challenges of present day.

The use of images of classic heroes of myths and legends occurs with a large share of distortion, giving modern features and character of thinking. Many heroes and gods (Achilles, Thor, etc.) become the embodiment of the idea of what a hero of modernity should be, and not a hero who is represented in the original myth. However, this is not the demythologization, but the "remifologization". Man recreates a myth again, using the types and attributes of the myth of the original. It is important to note that in this view the hero remains manifested only in circumstances; he is not a hero in and of itself. Only when he manifests his essence in action, in conquest, defense, overcoming difficulties, etc., he is recognized as a hero. Moreover, if earlier in myths the word "hero" defined a figure that not only committed acts, but also had a certain predisposition to it (birth from marriage of God and man, possessing supernormal abilities), now another vision of the problem is being imposed. Modern mass culture makes a person "become" a hero, we can often consider the plot in which an ordinary person behaves like a hero, and therefore, he is recognized by the society as a hero. At the same time, all these changes of myth and its transcriptions in the modern vision still remain within the framework of the classical myth: a person is told a story in which he sees either the ideal or the promised land, or which teaches a person to act in a certain way, repeating the actions of the mythological hero.

\section{CONCLUSION}

Indo-European poetics has generated a number of concepts that have served as major pillars for the further development of culture. The concepts of the king and the hero became the embodiment of the ideals of man and his behavior. To this day these concepts give forces for victories, no matter big or small. Myths never forced the man to simple repetition, but rather gave him confidence in the fact that once the perfect action of the hero can be repeated. The myth, thus, appears here not only as a form of literary creativity, but also as an important cultural and ideological component of the emerging and developing philosophical worldview. "It may seem that myths paralyze a person's initiative, because they seem immutable, in fact, they encourage a person to creativity, open up new prospects for his inventive mind. The myth gives a full confidence to a person that everything he is preparing to do have already been done once, it helps to drive away doubts that may arise regarding the results of actions taken. Why do you need to hesitate in front of the forthcoming voyage, if the Hero has already made it in legendary times? We only need to follow his example."[6]

\section{REFERENCES}

[1] West M.L. Indo-European poetry and myth. Oxford, University press, 2007 P.411.

[2] Nergreev I.O. Some religious aspects of royal power in the Norse cult of Odin. Journal Power. 2011'9. PP. 148-149.

[3] Tobin V.A. Mytho-Theology in Ancient Egypt. Journal of the American Research Center in Egypt.Vol. 25 (1988). P.171.

[4] West M.L. Indo-European poetry and myth. Oxford, University press, 2007.P. 432.

[5] Losev A.F. The myphology of the Greeks and Romans. Moscow, Mind, 1996. P. 41.

[6] Eliade M. Aspects of myth. Translated by V. Bolshakov.Moscow, Akademicheskiy prospect, 2010. PP. 143-144 